\section{Intersections}

Canadian Journal of Music

Revue canadienne de musique
Intersections CANADIAN JOURAL OR MUSIO

\title{
Northern Ways to Think About Music: Glenn Gould's Idea of North as an Aesthetic Category
}

\section{Markus Mantere}

Volume 25, numéro 1-2, 2005

Northern Perspectives on Music and Culture

URI : https://id.erudit.org/iderudit/1013307ar

DOI : https://doi.org/10.7202/1013307ar

Aller au sommaire du numéro

Éditeur(s)

Canadian University Music Society / Société de musique des universités canadiennes

ISSN

1911-0146 (imprimé)

1918-512X (numérique)

Découvrir la revue

Citer cet article

Mantere, M. (2005). Northern Ways to Think About Music: Glenn Gould's Idea of North as an Aesthetic Category. Intersections, 25(1-2), 86-112.

https://doi.org/10.7202/1013307ar
Résumé de l'article

Cet article examine le rôle joué par le concept de " Nord » dans la pensée musicale de Glenn Gould. Dans les écrits et entretiens de Gould, la signification $\mathrm{du}$ « Nord » est double :

(1) Le concept renvoie au phénomène musical et aux qualités (contrepoint, non virtuosité, austérité acoustique) qui étaient importantes pour Gould dans ses jugements de valeur sur la musique ; (2) Gould utilise le concept comme métaphore, lui permettant de réunir les idées d'isolement, d'utilisation de la technologie afin de "s'évader " créativement et celle de non-compétitivité au sein d'une esthétique cohérente et d'une perspective éthique. À travers l'étude d'écrits de Gould, le concept du " Nord " sera étudié afin d'établir un cadre herméneutique permettant de mieux apprécier et juger du sens musical de Gould.
Copyright @ C Canadian University Music Society / Société de musique des universités canadiennes, 2005
Ce document est protégé par la loi sur le droit d'auteur. L'utilisation des services d’Érudit (y compris la reproduction) est assujettie à sa politique d'utilisation que vous pouvez consulter en ligne.

https://apropos.erudit.org/fr/usagers/politique-dutilisation/ 


\title{
Northern Ways to Think About Music: GlenN Gould's IDEa of North as an Aesthetic Category
}

\author{
Markus Mantere
}

When I went to the north, I had no intention of writing about it or of referring to it even parenthetically in anything that I wrote. And yet, almost despite myself, I began to draw all sorts of metaphorical allusions on what was really a very limited knowledge of the country and $a$ very casual exposure to it. I found myself writing musical critiques, for instance, in which the north-the idea of the north-began to serve as a foil for other ideas and values that seemed to me depressingly urban oriented and spiritually limited thereby. Glenn Gould (GGR, 391)

The argument put forth implicity by the title of this essay - that the Canadian pianist Glenn Gould (1932-82) was a "northern" artist par excellence, and that the North plays a pivotal role in his aesthetic thought-may sound, to anyone familiar with Gould's life and work, merely obvious. Indeed, particularly after his 1964 retirement from the concert stage at the peak of his career, Gould became more and more fascinated with the northern part of his home country.

However, Gould cared not so much about the geography, history, population, or economy of the Canadian North, but rather about the symbolic and metaphorical meanings that the idea of North implied for him. The North, in his aesthetic thought, served from the very beginning as a metaphor for things Gould regarded as indispensable to his music-making: isolation, loneliness, and the ideal of artistic creation as an activity taking place outside institutions, canons and conventions of the art-world.

Gould's fascination with the North (in this abstract sense) plays itself out not only in his work-particularly in the Solitude Trilogy-as well as in many of his writings and interviews, but also in the public reception of his artistic persona. Gould is, in fact, reflected as a "northern artist" all over the place: in biographies and other commentaries about him, in photographs taken of him and used in many album covers of his recordings (about whose designs he was very fussy), and even in François Girard's award-winning movie, Thirty-Two Short Films about Glenn Gould (1993). Gould, in his own as well as in the eyes of others, became, over the course of his career, the "pianist from the North"1 whose eccentricities-his deliberate isolation from direct

1 Kevin Bazzana (2003, 293-94) cites two examples of this "northerliness" in Gould's public reception: David Dubal hears Gould's Bach as "sparse, abstract, yet mysterious," as "never pretty, 
social interaction, his hypochondria, his strange stage mannerisms, his harsh criticism of deities (like Mozart) of the Western art music canon-have formed "the myth of Gould" which is widely circulated in biographies, documentary films, and other commentaries on the pianist.

Gould was unquestionably an odd figure in the history of classical music performance. Indeed, as Edward Said (1991, 22-23) has put it, Gould "seemed never to have done anything that was not in some way purposefully eccentric," and for this reason his career seems like a "self-conscious counter-narrative to the careers of all other musicians." Seeing Gould apart from "all other musicians" may be an overstatement on Said's part,-what, were that the case, should we make of, say, Vladimir de Pachmann or Thelonius Monk?-but it is safe to say that Gould's eccentricity, together with his unconventional and provocative insights on music, have been crucial in evoking the huge public fascination with his character. Referring to Gould's cult status, Terry Teachout (2002) has written about "Gouldism"; the publicity of Gould's persona, which is almost comparable to that of pop stars, and the fascination created by it show no signs of weakening even now, twentythree years after his death. Gould has become a cult figure in and outside the world of classical music, an artist who is celebrated year after year in film festivals, panel discussions, congresses, and travelling exhibitions. Gould's North, together with the values and ideals that it stands for, is a prevalent theme in many of these events, as well as in the reception of Gould more generally.

Ultimately, Gould's North as an aesthetic construction concerns larger issues which are the focus of my essay. In addition to being Gould's topic of interest and a topos of his public reception, the North is, I assert, also a third, perhaps more interesting thing: it is, for Gould, an aesthetic ideal, a broad, multi-faceted aesthetic category which permeates his musical thought on many levels. The North, given this broader sense, becomes an abstract aesthetic ideal which had great impact on his interpretational choices and views on music. By "abstract" I mean that it is impossible to locate any particular instances, in Gould's writings or interviews, in which the North, in all its aspects, manifests itself; yet, I argue that the North always exists as a sort of hermeneutic backdrop against which to read and listen to Gould's musical discourse-his writings, interviews, and recordings. The North provides a backdrop for understanding Gould: a historical and cultural horizon of meaning in which Gould's musicianship and the ideas embedded in it, gain deeper meanings.

In Foucauldian terminology, Gould's writings on the North can be seen as "enunciative statements." Along this line of thought, the "enunciative func-

certainly not sensuous." Gould's Bach, in Dubal's ears, is "northern Bach, piercing the listener like the cold." George Steiner, in turn, hears Gould's Bach as "a luminosity, sharp and dry and as strangely intoxicating as a Canadian winter morning." 
tion," Gould's "northern-ness," is formed by statements, each of which "always belongs to a series as a whole, always plays a role among other statements, deriving support from them and distinguishing itself from them." According to Foucault, any enunciative statement "is always part of a network of statements, in which it has a role, however, minimal it may be, to play" (Foucault 1997, 99). ${ }^{2}$

How does one grasp the relationship of Gould's ideas to the intertextually constructed hermeneutic backdrop of the North? The path I've chosen is simple: it is to read Gould's writings, as well as transcripts of his interviews, in the context of other texts-texts dealing with the North. I am not only interested in the Canadian "discursive formation" 3 of the North, constructed in Canadian literature, movies, and music, but also in the North as a Romantic Austro-German aesthetic construction which is reflected in writings by Eduard Hanslick and Friedrich Nietzsche, among others.

These contexts, Canadian and Romantic discourses of the North, help to situate Gould's ideas in broader intellectual frameworks in which they resonate. Through the kind of contextual reading that I have undertaken to understand Gould, I've come to realize how close his musical thoughts come, at times, to Romantic ideas about music. Throughout his writings, however, Gould also maintains his own Canadian cultural identity-in spite of the fact that he sometimes, in these same texts, implicitly denies his being a product of his time and place.

My hermeneutic interpretation ${ }^{4}$ of Gould's ideas begins with an effort to reconstruct cultural, historical, and ideological frameworks to which his writings, interviews and even musical interpretations refer and from which they acquire their deeper meanings. In the end, by reading between various texts, I hope to arrive at a more contextualized, critical and theoretically elaborated view of one of the most fascinating musicians of all time.

2 Why not simply talk about the "discursive formation of the North" in Gould's thinking? Given the historically and culturally contextualizing approach that I use to read Gould, this would seem like the obvious choice. However, Foucault $(1997,55)$ explicitly states the following: “... discourse is not the majestically unfolding manifestation of a thinking, knowing, speaking subject, but, on the contrary, a totality, in which the dispersion of the subject and his discontinuity with himself may be determined." Gould's statements of the North rather take part in the Canadian discursive formation of the North than construct such a formation in and of themselves.

3 The term is used by Sherrill Grace (2002). By it, she refers, along Foucauldian lines, to a network of statements, all constructing the North.

4 The term "hermeneutic" has a long and rich history. In this essay it is used rather loosely, referring to an effort to gain deeper understanding to Gould's ideas by situating them in two intellectual and cultural contexts: Romantic and Canadian discourses of the North. Hermeneutic interpretation, in my essay, thus means striving for better understanding of Gould's musicianship not by "explaining" his ideas exhaustively, but rather by seeing them as part of, as well as interpreting them in, larger cultural and ideological horizons. "What is true of the written sources, that every sentence in them can be understood only on the basis of its context, is also true of their content" (Gadamer 1989, 177). 


\section{Meanings of North in Canada}

Among Canadian artists, Gould, in his fascination with the North-even if only as a metaphor-was nothing exceptional. The North, the barely accessible frontier, has always had huge importance for the Canadian identity and cultural imagination. One finds various representations of North in Canadian arts and letters all through the $20^{\text {th }}$ century and even earlier. Canadian artists, composers, writers, scientists, explorers, and even politicians have all had their own take on the North, which they then formulated in compositions, writings and statements.

As Sherrill Grace $(2002,50)$ puts it, the North "is a part of the imagined community called Canada and a defining characteristic, a crucial metonymy, for the whole." Indeed, the "vast hinterland of the north, with its sense of mystery and fear of the unknown" that Northrop Frye $(1971$, iii) refers to as the ground of Canadian identity, has fascinated visual artists such as Lawren Harris (together with other Group of Seven painters) and William Blair Bruce ever since the late $19^{\text {th }}$ century. The same could be said about composers: at a later point in this essay, I will take a look at what R. Murray Schafer, perhaps the most articulate contemporary Canadian composer on the significance of the North in music, has written about the North and its musical repercussions.

Grace has pointed out that "going north," as it is reflected in, for instance, various literary genres in Canada (novels, children's stories, and thrillers) means a number of things, many of them relevant to the formation of a Canadian identity. In Canadian literature, "going north" implies a certain softness and corruptness of southern, feminized civilization, as opposed to the promise the North holds out: "riches, renewed manhood, escape, freedom, a new beginning/rebirth, or even the release of death" (Grace 2002, 183). The North provides an opportunity to search (and discover) one's self, and to go where few men have ever gone before. The idea of "going north" also means to explore the unknown, to penetrate the terra incognita of the North, to simply obey the irresistible call of the unknown.

From an American perspective, Canada, in many ways, is the North: a country that reaches two thousand miles north from the American border, past sub-Arctic Churchill, Manitoba, up to the North Pole. Some forty percent of this second largest country in the world lies north of $60^{\circ}$, and it is this vast, mostly uninhabited and barely accessible area that has served, via art and literature, as a unifying concept for the Canadian cultural identity.

It has been suggested that the essence of being Canadian is in many ways constructed through a symbolic opposition to the Unites States and American culture. For instance, Northrop Frye (1982, 85-86) goes so far as to argue that "Canada has been steadily building up something like a North American counter-culture against the United States." Along the same lines, he continues: "identity only is identity when it becomes, not militant, but a way of defining oneself against something else" (Frye 1982, 75). This "something 
else" at the heart of the Canadian identity, Frye argues, refers to what many Canadians have regarded as the cultural and economical threat posed by the south's colonization of the north. ${ }^{5}$

Canadian identity is not built on what Frye $(1982,46)$ calls "a revolutionary tradition" like that of United States. Canada, unlike countries such as the United States, or my native Finland, for that matter, was never forced to create an identity for urgent political needs. For this reason, I believe, much of what really has come to be considered "Canadian" rests on an abstract, complex and multi-faceted idea of what it is that makes the country so unique in its relation to the rest of the world. Another aspect of Canadian "north-ness" to which Frye $(1982,49)$ refers, is the nation's close relationship with its natural surroundings. Both of these aspects of "being Canadian" have been important throughout the country's history.

Let me make clear the crux of my argument so far: the Idea of North, an idea of Ultima thule that directly influences relatively few Canadians, can neither be defined exactly, nor can its origin be traced back to any particular instance. It has nevertheless had a profound influence on Canadian culture and sensibility. I think it is safe to say that this idea of Canada's unique relation with the North has acted as a "mental signifier" to much of Canadian culture, literature, poetry, music, ${ }^{6}$ and to the cultural identity it has served to build.

This is essentially the same argument that Frye has put forth about Canadian identity. According to him, it has "always had something about it of a centrifugal movement into far distance" (Frye 1982, 77), and it is difficult to think of a better example of this cultural fascination with the unknown, with the sense of distance and of the unreachable sublime, than the importance the abstract idea of the North has for Canadian art and identity-and for Gould.

However, tracing the whole of Canadian identity to one central idea, as Frye and Margaret Atwood, in her famous essay "Survival" (1993), ${ }^{7}$ seem to

5 As far as this mechanism of formation of cultural identity goes, Canada's case is far from unique. For example, Finland, my native country, has, during the last two centuries of its cultural and political history, constructed much of its national identity within the historical context of having been ruled first by Sweden until 1809, which is when Finland became part of Russia. Following the Russian revolution and the country's withdrawal from World War I in 1917, Finland was finally able to claim independence due to political confusion in St. Petersburg. Culturally the struggle against Russia in the 1910 's had even more far-reaching consequences for what came to be Finnish cultural history: ever since the end of the nineteenth century, artists and composers, while being politically weak, made a great contribution to the construction of Finnish identity in their continuous definition of "Finnishness" through their work. The things we now regard as "Finnish," it could be argued, have more to do with artistic and literary achievements than with politics.

6 Of course there are other "signifiers" as well-I definitely am not arguing for a reduction of the whole Canadian culture and identity into a single hermeneutic principle! But still, North has been important for Canadian culture: one thinks of the Group of Seven paintings, novels by writers such as Margaret Atwood, and Michel Ondaatje, essays by Northrop Frye, music by R. Murray Schafer, Serge Garant, Harry Freedman, Violet Archer, and, of course, Glenn Gould. Many of these works manifest a unique fascination with individual survival, both literally and metaphorically, against the threat of annihilation.

7 Atwood's essay locates the idea of "survival" at the heart of Canadian identity. She writes about 
do, is always dangerous business. The North's relevance for Canada has come to be re-evaluated. Some scholars such as Renée Hulan have gone so far as to argue that "the north has little if anything to do with being Canadian today." She goes on to claim that the definition of Canada-as-North "is severely limited because it rests on the specious notion of national consciousness" (Hulan 2002, 27). In her richly documented book, Hulan argues that the "northern values" reflected in literature and the arts-self-sufficiency, independence, endurance-do not spring naturally from the North itself, but are artificially constructed on historically contingent ideas of gender and race.

Where do these two mutually exclusive arguments-Frye's and Atwood's Canada-as-North and Hulan's North-as-Myth-leave us at this point? Hulan sees great epistemological problems in what she calls Frye's "geographical determinism," and I definitely do agree with her. Gould, however, seems to have been far more uncritical of the North; he constantly spoke of its "modifying effect on the human character" and of the creative possibilities that the "experience of the land" offers for a thinking and self-reflective individual. Many other writers and artists, as we've already seen, have thought along similar lines. However, in this essay, we won't worry about whether or not the North is important for all Canadians, or whether or to what extent it is the cornerstone of all Canadian culture. It is, and this is the substance of my argument in this essay, the cornerstone of Gould's musical thought. This is why we can't leave the obviously controversial, abstract and even disputed idea of the Canadian North out of the discussion. Any hermeneutic effort to understand Glenn Gould's work - and much other Canadian art - cannot leave the controversial and complex North outside its scope.

\section{Gould's Construction of the North}

Gould wrote about the Idea of North on many occasions. In fact, one of his documentaries is titled The Idea of North. Commissioned by the Canadian Broadcasting Corporation (CBC) in 1967 to commemorate the passing of the British North American Act in 1867, The Idea of North is less a documentary of the Canadian North itself - the Inuit and other indigenous inhabitants, for instance, are markedly absent in Gould's documentary-than about Gould's own construction of the North and about his own aesthetic world-view. In his Introduction to the work, Gould tellingly writes about the Idea as "an excuse," as "an opportunity to examine that condition of solitude which is neither exclusive to the north nor a prerogative of those who go north" but which, for Gould, may appear more clearly to those "who have made, if only in their imagination, the journey north" (GGR, 393-394).

At the end of the day, as Gould himself says, the North has nothing to do with the "latitudinal factor." In the same Introduction, Gould explains (GGR,

it as a metaphor referring to Canadian "survival" against the harsh reality of nature. However, it also has another aspect: cultural survival against the culturally colonizing threat from the south. 
392) that most people who "go into the north" "become philosophers" because they "come to measure their own work and life" against the "staggering creative possibility" that the journey offers. However, fourteen years later he explicitly states, "... I don't think that the latitude is what made these people philosophers" (GGR, 456). It was rather their rejection of the norms and conventions of an ordinary life that made an impression on Gould. ${ }^{8}$ The North, in this later statement, is not about "going" anywhere but is rather about an individual creative ecstasy, something which, for Gould, takes place in solitude, outside the social and historical frameworks of art.

This idea of artistic and creative isolation is the key to understanding Gould's enigmatic statement in another essay: "art should be given the chance to phase itself out ... art is not inevitably benign" but, instead, "potentially destructive" (GGR, 324). This "potential destructiveness" refers to canons, conventions, and institutions, which act as barriers between art and the individual. In Gould's thought, music is more a process than a product, and musical creation is, by definition, a particular individual experience, ecstasy, which has no limits imposed from outside.

Ultimately "going North," for Gould, is not about a particular place, but about a particular experience-about defining oneself as an individual creative agent. It is about Atwood's "survival," if you will, amid the suffocating impact of traditions, conventions, and institutions on creative work. ${ }^{9}$ Gould's credo of individual creation can also be seen as underlying his enigmatic statement about "dreaming of a world where nobody cared what anybody else was doing" (GGR, 460), of a world devoid of systems of institutional qualification in which everyone has his or her "project at hand," enabled by the emancipatory potential of technology. I will return to this issue of technology later in this paper.

Going North, as it is reflected in Gould's documentary and thought, is ultimately an existential decision. In his 1964 address to the graduates of the Toronto Conservatory, Gould identified this notion of social and ideological detachment as a concept of "negation." In this highly interesting speech, Gould warns his listeners of "the dangers of positive thinking" - of reliance on conventions, norms and canons that make up the "system" of Western art music. "Invention upon which creative ideas depend," Gould argues in his address, must negate that system in order to search out the grounds for

8 Gould seems to have changed his mind on the question of "latitudinal factor." In a 1967 letter to James Lotz, one of his interviewees for the Idea of North documentary, Gould writes that "latitudinal factor does seem to have a modifying influence upon character" (GGSL, 105), whereas in his later comments, such as the one cited here, he departs from that view.

9 As Howard Fink $(1997,37)$ observes, The Idea of North was clearly autobiographical for Gould: it was written just three years after he had gone through a major identity shift from stage performer into a studio artist, and, in Fink's words, had "turned inward, to the solitude of the studio" which offered "womb-like security" for musical interpretation. Along the same lines, Gould's decision to abandon live concerts, was about artistic 'survival': he never felt at home on stage (like his arch-enemy Horowitz), and displayed an open dislike for the social aspects of concert institutions. 
creation in the realm of the possible, yet unexplored. In other words, Gould warns his listeners of "the futility of living too much by the advice of others" and of reliance on models imposed from outside (GGR, 3-5).

In Gould's documentary, one looks in vain for his attempt to formulate a coherent, normative "philosophy of [going] North." It is impossible to find a clear statement, in the Idea or elsewhere, regarding what "going North" means. As Kevin McNeilly $(1996,87)$ has observed, Gould's North, as reflected in the documentary, "is not a single topos, a functional 'idea' of North, but a site at which many voices and 'ideas' coalesce, antagonize, support, subvert, mingle, and separate." This North, McNeilly continues, is like "a name for a certain multiplicitous music, an imaginative zone in which the voices, noises and ideas of the human community"-which is formed by the shared experience of going North-"entangle and sound themselves out."

Gould regarded The Idea of North, together with his other documentaries, as a musical composition. His statements concerning it reflect his musical aesthetics. In a letter to Roy Vogt, one of his interviewees for the last work of the Solitude Trilogy, The Quiet in the Land,-which touches upon the social isolation of Mennonites from modern life-Gould ventures into a quasiphilosophical reflection on the nature of counterpoint in music:

I hope to devise a form for the programme which in musical terms could be called "contrapuntal." I really cannot apologize for that analogy, however, because in my view - and I think this view would be shared by most $20^{\text {th }}$ century, as opposed, perhaps, to $19^{\text {th }}$ century historians-counterpoint is not a dry academic exercise in motivic permutation but rather a method of composition in which, if all goes well, each individual voice lives a life of its own. ... in musical terms, the more accurate expression of the totalitarian ideal ... could be found in homophonic music in which one thematic strand-usually the soprano line-is permitted to become the focus of attention and in which all other voices are relegated to accompanimental roles. (GGSL, 150)

In an earlier letter in which he comments on Mozart's concertos to the famous music critic B.H. Haggin, Gould touches upon this same issue. According to Gould, "the whole idea of a melodic attribute as distinguished from the component parts of a harmonic environment"-that is to say, separating melody and harmony as individual entities which is a prevalent feature in the predominantly homophonic Classical style- "has always seemed to me anti-structural and even, dare I say it, undemocratic"(GGSL, 109). ${ }^{10}$

10 Gould's commentary here is very similar with Heinrich Schenker's (1868-1935) idea of synthesis: the conception of a musical work as an organic whole, in which every part of it is supported by the underlying background structure, Ursatz. On other similarities between Gould's and Schenker's ideas, see Bazzana (1997, esp. 92-93, 151-52, 216-17, 223, 226). 
Thus homophonic musical texture, in which one line "is permitted to become the focus of attention" at the cost of others, seems, according to Gould, to function as an iconic representation of a "totalitarian ideal." These quasi-philosophical considerations are the key to understanding the metaphorical meanings of counterpoint - the central aesthetic idea in the Solitude Trilogy-in Gould's thought. Homophonic texture privileges one line at the cost of others, while counterpoint, for Gould, lays bare the antagonistic, diverse lines in the musical structure. Counterpoint, through its very mode of unfolding as a musical narrative, leads the listener to dissect the musical discourse. Counterpoint is like the North itself: a multi-voiced topos, which, by its nature, is more a way of thinking, a process, than something normatively defined. ${ }^{11}$

In the next section I will have more to say about the ethical implications that counterpoint carries in Gould's thinking. However, let me conclude this section by arguing that counterpoint, both through The Idea of North and in Gould's musical thought more generally, implies a "democratic," diverse, polyphonic, and multi-levelled existential and musical presence in which there is no real centre of attention, and which he clearly associated with the North.

As far as the experience of music is concerned, Gould was inspired by a McLuhanesque idea of a polyphonic "global village," a virtual "community of ecstasy" (Guertin 1988, 234) mediated by technology, which Gould saw as a way out of public concerts. In music itself, counterpoint embodies a structurally transparent, multi-dimensional musical discourse, in which every individual line has space-and by definition an aesthetic right-to flourish. In the Idea, the mode of listening to this diverse and multi-levelled whole is explicitly named "northern listening," which, according to McNeilly (1996, 87), "is a means of attending to others ... a means of participating, directly, crucially, in the multiple streams of human presence in the world." This, for Gould, is the aesthetic and ethical essence of being in, and going to, the North.

\section{The North in Music}

As Geoffrey Payzant $(1997,55)$ observes, Gould's musical preferences were "strongly influenced by northerliness." Gould was always "ill at ease with the passionate, sunny Mediterranean temperament in all its manifestations, but particularly the Spanish bullfight and the Italian opera." Kevin Bazzana

11 Setting the North aside for a moment, Gould's argument on counterpoint is essentially Adornian. As Leppert $(2002,522)$ puts it, polyphony (and by extension, counterpoint), exemplified by chamber music, functions, for Adorno, as a musical enactment of "lost sociability," of "musical conversation, musical give and take, musical sharing, musical support of intertwining voices: in short, an enactment of mutual respect and friendship." In chamber music, Leppert argues, "Adorno could imagine the possibility of what otherwise seemed unavailable: a society that was actually social (or sociable)." On other similarities between Adorno and Gould, see Bazzana (1997, 21-24) and Said (1991, 29; 2000, $6-8,10-12)$. 
$(2003,293)$ says essentially the same thing: for Gould, "North was more than a place," it was "a way of life, a way of thinking, and he associated his personal and aesthetic values with a Nordic temperament."

Gould said as much on various occasions. For instance, in a 1960 interview with Vincent Tovell, Gould declares that he "squirms with Verdi and wriggles with Puccini" because of his feeling "intensely uncomfortable with this music" (AGG, 87). In a letter written 14 years later, Gould blames his "general francophobia" (GGSL, 216) for not doodling with French music beyond his own tongue-in-cheek transcription of Ravel's La Valse and Debussy's Première Rhapsodie. ${ }^{12}$

Moreover, the "Mediterranean" element that Gould so despised in Ravel and Debussy is not geographically defined. It seems to function more as a group of stylistic criteria in his judgment of various works, even of music composed outside the actual geographical area to which the word "Mediterranean" refers. The music of Mozart-a composer who, in Gould's mind, "died rather too late than too early"-is a case in point. For Gould, it represented a "pretension to self-sufficiency" and displays, in addition to its "totalitarian" homophonic style, "hedonistic" elements, which he abhorred. On a more detailed level, Mozart's sforzandi are, in Gould's eyes, musical representations of theatricality to which "my puritan soul strenuously objects" (GGR, 36). ${ }^{13}$

The "explosion of simultaneous ideas," which is how Gould described counterpoint, is one of the cornerstones of his musical preferences, as we've already seen. It is no exaggeration to say that in all the music that Gould valued, counterpoint and polyphony were prevalent features. And where this element is lacking, Gould re-composes it into the music. Indeed, anyone familiar with Gould's controversial complete recording of Mozart's piano sonatas can recall the way he "adds vitamins" (Gould's phrase) to the otherwise mostly homophonic texture. Gould creates counterpoint through accentuation and prolongation of certain carefully selected notes over their notational duration in what is essentially a harmonic and homophonic mu-

12 Both works were performed within a series of radio programs titled "Music in Our Time." La Valse was performed in "The Flight from Order, 1910-1920" (1975), and the Rhapsodie, with the clarinettist James Campbell, in "The Age of Ecstasy" (1974). Both are now available as commercial recordings in the Sony Classical Glenn Gould series.

13 Gould's views on Mozart, as his own comments give reason to suppose (GGR, 43), may have been influenced by Jean Le Moyne, a journalist and self-made theologist from Montréal whom Gould interviewed in one of his radio programs. Le Moyne's arguments against Mozart resemble Gould's: "I begrudge the entertainment aspect of Mozartian aesthetics. His music is generally devoid of supernatural content and it locks us up in a world of pure entertainment, which diverts attention from what is essential, urgent and uniquely necessary" (Le Moyne 1966, 249). In another essay, Le Moyne writes about the fugue as "the supreme musical form," as a kind of musical representation of God's universe which is "a counterpointing of all creations from angels to the electron." Musical counterpoint, for Le Moyne, refers to "counterpoint cadenced to the promised coming of Christ in glory, the total Christ, the summation of all things, the centre of all attention" (255). Le Moyne's view is, as it were, a "spiritualized" version of Gould's argument. 
sical situation, the Alberti bass (Bazzana 1997, 145). Gould "forces" counterpoint on Mozart's music, $x$-raying the musical skeleton while totally sidestepping the musical elegance, finesse and melodic invention which are its virtues.

In doing this, Gould's aim is interesting and typical of his music-making: he extends his criticism of Mozart, expressed in numerous writings and interviews, to musical interpretation and transformed it into an audible commentary on the music's value. The analytical bent in his interpretations is almost always obvious. For instance, when he describes his first encounter with KV 333 to Bruno Monsaingeon (GGR, 34), an interpretation which supposedly shocked his teacher, he explains that he wanted to draw attention to "why Mozart would ignore so many obvious canonic opportunities for the left hand." Similar comments reflecting his interpretation as analysis would not be hard to find.

Mozart's "theatricality" and the "pretension to self-sufficiency" which Gould found so intolerable are also aspects of this music's idiomatic, pianistic substance. Mozart's piano sonatas offered the merely "tactile pleasure" of running his "fingers up and down the keys, exploiting all those scales and arpeggios" (GGR, 33).

So far we've not tackled the most important question: what is it in music that made Gould "squirm and wriggle" with Verdi and Puccini? What is the musical element of "theatricality" in Mozart to which Gould's "puritan soul" "strenuously objects"? What is this "music from the South" made of?

Gould's first biographer, Otto Friedrich $(1990,175)$, wrote that Gould "felt an almost mystical sense of that Canadian North and of its connections to the rest of the northern world." It is no coincidence that Gould's oeuvre as a recording artist consists, for the most part, of works by Bach, Beethoven, Wagner, Brahms, Schoenberg, and Strauss, and that he chose to record little-known curiosities by Sibelius and the Norwegian atonalist Fartein Valen-not to mention those of various Canadian composers-rather than works by Chopin, Rachmaninov, or Liszt. In one of his last interviews, he expressed the astonishing opinion that "the whole centre core of the piano recital repertoire is a colossal waste of time" (GGR, 453, editor's emphasis). There is no doubt that he genuinely hated the passionate Italian opera, theatrical Mozart, as well as the works of Debussy, Ravel, and Chopin, all of which, in Gould's opinion, relied too much on the sensual aspect of music and were not structurally interesting.

However, Gould did not love all of Bach, Sibelius, or Wagner, and the simplistic conclusion with which Friedrich leaves the reader-that the place of origin of the music had, in and of itself, aesthetic relevance for Gould-is only part of the truth. True, Gould was, at times, guilty of stereotypical assertions of whole nations. In his 1962 interview with Bernard Asbell, (AGG, 187) he refers to "Latin Americans" as "savages," whose "heartless," "ruthless" and "senseless" tendency to enjoy bullfights is aesthetically analogous to 
listening to music in concerts (!). In his 1968 interview with John McClure, Gould argues that, in both of these rituals-concerts and bullfights-the audience is there waiting for "something to happen":

There's a very curious and almost sadistic lust for blood that overcomes the concert listener. There's a waiting for it to happen, a waiting for the horn to fluff, a waiting for the strings to become ragged, a waiting for the conductor to subdivide ... there's a kind of gladiatorial instinct that comes upon the hardened, the case-hardened concert-goer, which is why I don't like him as a breed, and I don't trust him, and I wouldn't want one as a friend. (Gould 2001, 50) ${ }^{14}$

Interestingly, Gould uses almost the same words in his comments on "the artistic hostility" of "sun-baked societies" - a not-too-sophisticated reference to Italy-who have "built an operatic tradition in which their primal instinct for gladiatorial combat has found a more gracious but thinly disguised sublimation" (GGR, 247). It is the passionate, emotional, virtuosic, and flamboyant quality in Italian opera which clearly bothered Gould. Music from the "South," reduced music to "a momentary ejection of adrenaline," whereas, for him, the true purpose of art was a "gradual, life-long construction of a state of wonder and serenity" (GGR, 246).

Music, at its best, is something beyond emotions, excitement and display of virtuosity. As Bazzana (1997, 33) points out, "contrapuntal ingenuity, harmonic sophistication, and motivic development" were features in all Gould's favourite works, and he tended to judge musical works negatively according to the extent to which they emphasized their own "pianistic," idiomatic qualities and thus put forward the virtuosity of their performers. For instance, in writing about Bach's Die Kunst der Fuge, Gould writes about the composer as "withdrawing from the pragmatic concerns of music making into an idealized world of uncompromised invention" and, more generally, about the "magnificent indifference to specific sonority" as indicative of the "universality of Bach" (GGR, 17, 21).

Considering Gould's unwavering belief in music's detachment from any particular instrument-and, by extension, an act of performance-it is possible to understand how Gould could deplore works such as Chromatic Fantasy and the Toccatas, while almost in the same breath be full of praise for the "universality" of the composer. Bach's "withdrawal from the pragmatic concerns of music-making" in Die Kunst der Fuge also meant, for Gould, a withdrawal from the physical and corporeal aspect of music. Thus music becomes a pure, abstract, non-idiomatic entity.

14 In an interview given two years earlier (1966) Gould uses even stronger words: "I detest audiences, not in their individual components, but en masse, I detest audiences. I think they are a force of evil." (http://archives.cbc.ca/400d.asp?id=1-74-320-1686). 
Gould's distinction between music as sound-as idiomatic and physical entity-and music as structure was, at heart, motivated also by ethical considerations. "Competition, rather than money," was "the source of all evil," (GGR, 41) and it is fascinating to observe how Gould converts this essentially ethical maxim into a basis for making aesthetic judgments. Whole genres of music had moral implications for Gould: the competition principle, so thoroughly present in the piano concerto, bothered Gould so much, that most of Gould's interpretations of concertos tried in different ways to do away with the public display of virtuosity and the musical antagonism of the soloist with the ensemble, which are the aesthetic substance of the genre. Rather, Gould saw the soloist, in an almost Baroque fashion, as part of the ensemble-as only one line in the orchestral structure. The virtuosity of the soloist, in Gould's thinking, is not a legitimate aesthetic'substance of the music.

In the next section of this essay I will have more to say about the relationship between Gould's ideas and those of Eduard Hanslick, who with great success codified the nineteenth-century idea of absolute music in his tract $O n$ the Musically Beautiful (1854). However, to conclude the present discussion, I will elaborate on two central issues regarding this relationship.

First of all, we've seen that structure, not the sonic aspect of music, is given priority in Gould's musical thought, as has been observed in various commentaries (Payzant 1997, 73-88; Bazzana 1997, 36-58). The audible end-result of the interpretation process was an extension of his analytical re-composing of the work, rather than merely an execution of the score. Interestingly, in 1980 Gould told Jim Aikin, that "premise number one," in his piano playing, "is to try to forget that I'm playing the piano." In a re-creative interpretation of any given musical work, he doesn't "want to be aware that anything specifically pianistic is being done in order to bring out whatever structural design" he has in mind (AGG, 260). This kind of instrumental indifference to playing can be found throughout Gould's public statements. In the lengthy interview with Jonathan Cott $(1984,40)$, he noted that "an analytical completeness [Cott's italics] ... is theoretically possible as long as you stay away from the piano. The moment you go to it you're going to diminish that completeness by tactile compromise."

This idea of separating music's substance, its inner meaning, from its sonic aspect, was, of course, central in Romantic aesthetics. It is particularly pertinent to the idea of a musical work as an autonomous object, ontologically independent of its performance. As Carl Dahlhaus observed, referring to the writings of E.T.A. Hoffmann and Friedrich Schlegel, two of the pivotal figures of early $19^{\text {th }}$-century music criticism:

To understand music means ... grasping the structure, the harmonic and thematic logic of a work, so as to be able to fathom its aesthetic meaning, a meaning that remains inaccessible to mere mindless enthusiasm. (Dahlhaus 1989, 91) 
This kind of physical and instrumental transcendence allowed music to function as "language above language," as an "intimation of the absolute," a metaphysical reality. These terms also turned experiencing music into an aesthetic contemplation, a devotion to the work, which came to be separated from pure enjoyment. ${ }^{15}$ This kind of (post-Kantian) listening to music as meaningful structures meant "immersing oneself in the internal workings of a piece of music as though nothing else in the world existed" (Dahlhaus 1989, 95).

But while Romanticism turned the listener's-and interpreter's-devotion and aesthetic duty to the work into a notion of Werktreue, ${ }^{16}$ and the notion of interpreting musical works into an exegesis of the composer's intentions, Gould, in a very peculiar way, departs from these ideals. Having argued that musical works are structures, independent of their sonic realisations and that musical interpretation is mental, not physical activity - Gould was nonetheless not willing to take the next step that the Romantics took: to subscribe to the view that musical interpretation means mediating a composer's intentions, expressed in autonomous, original musical structures. On the contrary, "the performer has to have faith," Gould argues, "that he is doing, even blindly, the right thing, that he may be finding interpretive possibilities not wholly realized even by the composer" (AGG, 194).

In Gould's thinking, the performer does not have an ethical duty to the composer but to himself. Enabled by technology, the modern artist and listener are "rapidly and quite properly learning to appreciate the elements of aesthetic narcissism ... and are awakening to the challenge that each man contemplatively create his own divinity" (GGR, 246). This "divinity" is not the metaphysical reality in which the substance of music, the composer's intentions, are to be uncovered through aesthetic contemplation, but a private, isolated, and re-creative ecstasy which Gould considered to be the goal of all artistic activity. This notion of artistic experience-both the listener's and the artist's-as a private, isolated and contemplative activity is something which both separates Gould from, as well as connects him to, the Romantic discourse of music. Gould has, as it were, one foot in the Romantic culture of musical "innerness"-in his emphasis on music as a private phenomenon and his view of listening to music as contemplation-and another in a kind of proto-post-modern philosophy of art, particularly when we consider his notions of interpretation as an active, re-creative process (Nattiez 1996, 30-33; Bazzana 1997, 83-84, 255). This conflict does not find any resolution in Gould's thought.

15 For a detailed discussion of aesthetic contemplation as a form of devotion see Dahlhaus (1991, 78-87).

16 For an excellent discussion of the historical origin of the term, see Lydia Goehr (1989). 


\section{Arctic Resonances and the Shadow of Hanslick}

Gould's views of North in music have peculiar similarities with those of other Canadian composers, notably R. Murray Schafer. Compare, for instance, Schafer's view of the purpose of art being "to affect a change in our existential condition" (Schafer 1991, 32; quoted in Harley 1998, 125) with Gould's oft-cited goal of art as the "gradual, life-long construction of a state of wonder and serenity" (GGR, 246). Both men also wished to do away with the distinction between life and art: Gould because of the artificiality of the canons and conventions and the emancipation of everyone's creative potential outside the art-institution; Schafer because he wanted to widen the concept of art to cover all human life.

The most striking similarity, however, between Gould and Schafer comes to the fore in the latter's aesthetic manifesto, Music in the Cold, written in 1975. The document is in fact a series of short poems which, taken together, narrate the North being invaded by the South.

You know what happened next

The people came.

I became we.

We opened up the country.

We chased the animals from one end of the country to the other for their felt hat business.

We slaughtered the trees, sending the tall ones for masts, mashing up the rest for newspapers. They taught us the domino technique of felling seven trees with one cut, more than we ever needed; but there was always a market for them....

No one had seen snow for fifty years, except for a few outdoor freaks who flew up to Yukon for weekends to chase polar bears on snowmobiles. We lived on avocados and flamingo-meat.

We all grew double chins. ...

But no one worked anymore.

Leisure had arrived.

Leisure killed art.

The correlative of leisure is entertainment. (Schafer 1984, 67-70)

One easily hears the melancholic substance of Schafer's manifesto: the comfortable lifestyle of southern "civilization" kills off everything that is original and important for being and living in the North. It standardizes life and extends the culture of consumerism to the previously unspoiled northern territory.

Music in the Cold is, as Grace $(2002,137)$ points out, "an important statement ... a lyrical lament for a lost northern ideal and an aggressive political challenge to the status quo of 'slack-jawed indifference' and creeping Americanization"; it is a story "of a northern nation run amok by becoming its opposite: the South."

With regard to my argument presented here, I find what Schafer says about "northern" art particularly interesting. 
The snows came early this year.

It is the beginning of a new ice age.

The wind howls at our ears as we dig for wood in the snow,

and I wonder

what this will do for music?

It'll toughen it up.

It'll reduce it to the lean shape, maybe even bare bones.

And its form will become clear as icicle.

Northern geography is all form.

Southern geography is colour and texture.

A northern glacier is brute form.

A southern jungle is juicy....

The art of the North is the art of restraint.

The art of the South is the art of excess.

It is the soft art of dancing girls and of the slobber.

Of necessity, conservation of energy begins in the North.

It begins with lean stomach and strong bow.

Prodigality is centred in the South,

and the waste of energy begins at the mouth. Some of this waste energy is

called art.

It is thought that warm climates are the best incubators of it. ...

The art of the North is composed of tiny events magnified.

Those accustomed to fat events that don't matter, or to many events, miss these details. (Shafer 1984, 64-65)

My purpose in making these lengthy quotations has been to demonstrate the dichotomy between North and South in Schafer's fascinating text:

\begin{tabular}{|c|c|}
\hline North: & South: \\
\hline winter & summer \\
\hline formal, structure & technicolor, surface \\
\hline restraint & excess \\
\hline lean stomach, fitness & dancing girls, slobber \\
\hline strong bow, work & flatulence, ease \\
\hline conservation of energy & prodigality \\
\hline tiny events magnified & fast, many events \\
\hline art & entertainment \\
\hline
\end{tabular}

In the program notes to his orchestral piece North/White-which, according to Grace $(2002,139)$, is "the closest musical formulation of the ideas in Music in the Cold"-Schafer (1984, 62-63) writes that "Canadians are about to be deprived of the 'idea of the North', which is at the core of the Canadian identity." The North, for Schafer (and Gould, for that matter), "is a place of austerity, of spaciousness and loneliness; the North is pure; the North is temptationless" (Schafer 1984, 63). The North exhibits a kind of utopia of possibilities similar to 
Gould's ideas of North, though Schafer's views are somewhat spiced up with a touch of Canadian nationalism and notions of cultural ecology.

Gould's view of music - as abstract, non-idiomatic, structural, austere, and contrapuntal-fits together strikingly well with Schafer's construction of the North. What does a work such as Die Kunst der Fuge represent for Gould if not Schafer's "structure," "form clear as icicle," as opposed to "surface" and "colour" of, say, Debussy's or Ravel's music? What else does an idiomatically indifferent Bach fugue represent for Gould, than "restraint" or "tiny [thematic] events magnified," as opposed to the Southern "excess" and "ease" that virtuosic works of Liszt and the melodic elegance of Mozart display?

Gould's views on the "northern" listening to music as analytical, contemplative and individual activity, ideally taking place in privacy, also have certain resonances with Eduard Hanslick's conception of listening as aesthetic contemplation. In his On the Musically Beautiful, Hanslick writes:

The tyranny of the upper vocal part among the Italians has one main cause in the mental indolence of those people, for whom the sustained penetration with which the northerner likes to follow an ingenious web of harmonic and contrapuntal activity is beyond reach. So the pleasure is more superficial for hearers whose mental activity is slight, and such musical tosspots are able to consume such quantities of music as make the artistic soul shudder. (Hanslick 1986, 64)

Just like Gould in his depiction of the "sunburned" as an aesthetically degenerated people, enjoying music in the emotional flush of adrenaline, and in his view of Latin Americans as "savages," describing their experience of music as analogous to the bull fight, Hanslick excludes Italians from the "northern" contemplation of music. This, for Hanslick, means "sustained penetration" of "harmonic and contrapuntal activity" which Germans are, in his view, capable of. Gould never mentions Hanslick in any of his writings or interviews, and it is unlikely that Hanslick's writings ever had any direct influence on him. Rather we are talking about a larger discourse on absolute music which originated in the late $18^{\text {th }}$ century, was crystallized through Hanslick's treatise (as well as E.T.A. Hoffmann's music criticism), and with which some of Gould's ideas resonate.

It would, however, be a mistake to suppose that Hanslick's views represent the only Austro-German $19^{\text {th }}$-century view of contemplative music listening, which, more than a century later, is repeated in Gould's writings. Romantic composers and philosophers of music were far from unanimous on what they considered to be important in music and on determining how one should listen to it. ${ }^{17}$ Hanslick's treatise was itself an argument, in an interesting

17 For instance, Dahlhaus (1989, 8-15) drew up a relationship within which Rossini and Beethoven

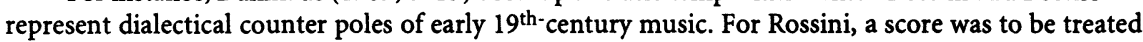
as a mere recipe for a performance, whereas a symphony by Beethoven was to be seen as an autonomous work of art, complete within itself. 
ongoing aesthetic debate of the 1850 's, against program music and "aesthetics of feeling."

Friedrich Nietzsche's harsh criticism of Wagner, based on an entirely different set of aesthetic principles, is well known. As opposed to Wagner's, which "sweats," Bizet's music "approaches lightly, supplely, politely." It "treats the listener as intelligent, as if himself a musician" and enables Nietzsche to "become a better human being" and also "a better musician, a better listener" (Nietzsche 1967, 157). "Il faut méditerraniser la musique," Nietzsche goes on to say, and in the same breath does away with values we've come to associate with absolute music:

It [Wagner's music] has filled our whole life with its rattling about 'devotion,' about 'loyalty,' about 'purity,' and with its praise of chastity it withdrew from the corrupted world.-And we believed in these things. (Nietzsche 1967, 160)

In another essay, Beyond Good and Evil, Nietzsche elaborates on his idea of "mediterranizing" music in more detail:

Against German ${ }^{18}$ music I feel all sorts of precautions should be taken. Suppose one loves the South as I love it, as a great school of convalescence, for all the diseases of senses and spirit, as a tremendous abundance of sun and transfiguration by sun, spreading itself over an autonomous existence which believes in itself: well, such a person will learn to be somewhat on guard against German music because, by spoiling his taste again, it will also spoil his health again. Such a southerner, not by descent but by faith, must, if he dreams of the future of music, also dream of the redemption of music from the north and have in his ears the prelude to a deeper, mightier, perhaps wickeder and more mysterious music, a supra-German music which does not fade, turn yellow, turn pale at the sight of the blue voluptuous sea and the luminous sky of the Mediterranean, as all German music does. (Nietzsche 2005, 255)

Now what should we make of these notions in relation to Gould's ideas of music? First of all, Gould certainly did not subscribe to Nietzsche's anti-German views on music, as we've seen. Even though the two had, somewhat surprisingly, a mutual favourite in Bizet-whose Variations chromatiques, for Gould, was "one of the very few masterpieces for solo piano to emerge from the third quarter of the nineteenth century" (GGR, 78) - "Mediterranean" culture, for Gould generally, represented everything he despised: competition, virtuosity, sensuality, emotionality, flashing displays of musical colour (think of Debussy), and so on. Music, in his view, was something else: a

18 Nietzsche's judgement of German music in general and Wagner's music in particular is interesting because it completely eludes the conflict between absolute music (Hanslick) and program music (Wagner). 
rational, abstract and mental activity, in which the interpreter's analytic relationship with the musical structure is a priority.

As far as their views on musical values are concerned, it would seem that Gould and Nietzsche are totally opposites. Gould, we would be justified to conclude, abhors Nietzsche's "tremendous abundance of sun and transfiguration by sun" represented in music, and there is certainly no more meeting of the minds on the significance of Wagner for the history of music.

However, two similarities between their views strike me as noteworthy here. First of all, both Nietzsche and Gould associate the "South" with sensuality, lightness, spontaneity, colour, dance, even corporeality. The musical North, on the contrary, is represented by structure, musical development, seriousness, music's anti-sonorous quality, and so on. Whereas Nietzsche clearly departs from the latter values-note that he even denounces "devotion," "loyalty," and "purity" in the experience of music-in favour of the southern light-hearted enjoyment, Gould sticks to his neo-Romantic aesthetics, as far as musical idealism is concerned. However, in spite of their different reactions to these values, the two share essentially the same view as to what northern and southern qualities are in music.

Second, both Nietzsche and Gould depart from the Romantic notion of experiencing a musical work as aesthetic (and even ethical) devotion. Nietzsche's reason for this seems to be the idea that this kind of devotion makes corporeal enjoyment impossible-Hanslick's view of aesthetic contemplation certainly does-whereas Gould, in the end, regards any historical and biographical information about a given musical work as irrelevant. Gould's idea of aesthetic contemplation, as it were, detaches its object from time, place, and its composer's intentions.

Gould assigned the re-creative function in music-making to technology. It is Gould's unwavering belief in the emancipatory potential of technology-as the listener's and artist's "gate" to the North - to which I turn to conclude my essay.

\section{Gould's TeCHNOLOGICAL UTOPIA}

Music's abstract, non-idiomatic nature, structure, and austerity are not the only cornerstones of Gould's aesthetic thought. The idea of music-as well as the interpretation of it-understood as an essentially ahistorical entity was also of particular importance to him, a theme on which he elaborated at length in one of his most important writings, "Forgery and Imitation in the Creative Process." 19

19 This essay was first published in French (Gould 1985) and published in its original English posthumously. Most likely it originated as a lecture. In an unpublished letter to Arthur Darack, editor of The Cincinnati Enquirer, Gould (1963) writes: "the piece on forgery, etc. which we discussed when I was in Cincinnati has now grown into a ten thousand word lecture which is having its debut next month at the University of Toronto[.]" No other documents survive regarding this lecture. 
In this essay, Gould $(1996,8)$ explains that technology makes it possible for the artist to search for the "supra-historical aesthetic value" in his or her interpretation of a given musical work-a value which has nothing to do with the composer and the time of composition. Technology is of key importance here. Through technology's potential, Gould argues, it will become possible to create an aesthetic environment, in which the experience of art will be immediate and individual. This essentially private relation to art will become possible because the identity and historical context of the author will be simply irrelevant in the technologically mediated aesthetic experience.

Technology fulfils its potential by emancipating music from its historical context. Working with recording technology enables the artist to "create an environment where time turns in upon itself, where, as in a cloister, one is able to withstand the frantic pursuit of the transient, of the moment-to-moment, day-by-day succession of events" (Gould 1998, 4). Technology, as Gould writes in his oft-cited classic "Prospects of Recording," can create for the listener a "climate in which biographical data and chronological assumption can no longer be the cornerstone for judgments about art" (GGR, 352). This detachment of music from its historical context is essential for true aesthetic judgment to occur. Gould argues that as soon as the listener creates a link between a work of art and its biographical and historical contexts, this background information becomes a dominating factor in the act of judgment. This process, Gould pessimistically thinks, is so common, that most of the aesthetic judgments we make spring from the background information of the work of art, rather than from our experience of the aesthetic object itself. In the "Forgery and Imitation" essay this point becomes crystal clear:

[W]e associate, to as large extent as we can, the predominantly identifiable historical traits with the significant works of art of their time and we build into our interpretation of these works processes of identification which, because of this, are mixed up with all sorts of extraneous ideas and themes which have extraordinarily little to do with the way the works themselves have been formulated. (Gould 1996, 7)

For Gould, the historical framework is of no significance in making aesthetic judgments and in composing musical works. Gould's favourite example, which he mentions in at least two of his essays, is a hypothetical piano piece played in Viennese-Classical style that he would improvise before an audience. The audience's reaction to the work, Gould plausibly assumes, would be radically different depending on who the composer of the music is. If it were, say, Vivaldi, the work would be a musicological sensation, proof of the composer's visionary potential-his ability to foresee music's historical progress. If, on the contrary, the composer would be announced to be Brahms or Mendelssohn, the work would merely be judged as a curiosity, a document from the "immature" stages of the composer's development (Gould 1996, 5). 
Gould found aesthetic judgements based on such shaky grounds highly problematic. He does not accept the evolutionary conception of history in which the value of art depends on its "originality" and its uniqueness in relation to its historical predecessors. I have earlier (Mantere 2002) written about Gould's "ethics of isolation"-the glorification of solitude as essential for creative work-and here it seems that this theme of isolation extends to his conception of history, to an idea of "historical isolation." Gould clearly values artists and composers who are somehow "out of sync" with their times, who, through their work, refuse to obey "the tyranny of the Zeitgeist." Gould's favourite example of this artistic and historical non-conformism is, of course, Richard Strauss, who, in Gould's words, is "an example of the man who makes richer his own time by not being of it; who speaks for all generations by being of none" (GGR, 92). Here, Gould makes a radical aesthetic move. He departs from a basic axiom in Western aesthetics: the idea that a given artwork has an important connection to its time and place. According to this axiom, these contexts are relevant to the interpretation, as well as the appreciation, of the work. In Benjaminian terminology, Gould rejects the historical aura of a given artwork as the legitimate basis for its aesthetic appreciation. Ideally, composing, interpreting, as well as listening to music are ahistorical activities in which chronological, topological, and biographical contexts have no importance. What matters is not the historical context of art, but the art itself and the re-creative experience of it.

Gould's belief in the "charity of the machine"-a metaphor he borrows from Le Moyne-associates technology with ethics. ${ }^{20}$ Le Moyne saw technology as an all-encompassing network, impossible to bypass in ordinary life. Technology, in this sense, has gained the status of "second nature," through which all human action is mediated. What makes his ideas exceptional is that he did not regard technology as a threat, but as a benefit to humankind.

For Gould, Le Moyne's greatest contribution, which he unreservedly embraced, was the idea that technology is "not there to hurt people, to hinder them to impede them, to get in the way of human contact." Paraphrasing Le Moyne, Gould states that technology "is there to speed it, to make it more direct and more immediate, and to remove people from the very things-the self-conscious things, the competitive things-that are detrimental to society in fact" (GGR, 290).

Technology, Gould argues, imposes "upon art a notion of morality which transcends the idea of art itself," and the "evolution of man in response to his technology ... has enabled him to operate at increasing distances from, to be increasingly out of touch with, his animal response to confrontation" (GGR, 355). In other words, technology brings about not only the emancipation of

20 Matthew McFarlane (2002) has discussed Gould's ideas in relation to Le Moyne and Teilhard de Chardin, both intellectuals whose influence Gould acknowledged. I have benefited greatly from reading his ideas. 
the individual's creative potential, but also the possibility of control, the capacity to "operate at a distance," which is how Payzant (1997) expresses what he calls Gould's "new philosophy" of making music.

Gould's technological optimism makes him very much an intellectual of his time and place, a point first raised by Paul Théberge (1986) in his remarkable article. He argues that there is a strong connection between Gould's and Marshall McLuhan's ideas, which has been strangely unnoticed in earlier Gould-literature. Through a detailed and richly documented discussion, Théberge (1986, 110-11) shows how McLuhan's notion of technology as an "extension" of man, as an "environment" which has become a kind of "second nature" in the modern world, is just one of the ideas that had great influence on Gould's thinking. He also discusses the similarity of their views regarding a number of other issues: the moral implications of technology; the future of live arts in a technologically mediated world; the change in the nature of the musical experience that technology has brought about; the merging of "life" and "art" through technology, etc. The influence of McLuhan on Gould's thinking comes as no surprise-for instance, in the interview with Cott $(1984,102)$, Gould says he "admires McLuhan very much." Throughout his writings, Gould also uses terms that often bring his compatriot to mind: "aesthetic narcissism," "tactile" sound, and "linearity" of radio.

Gould's fascination with technology is also something that makes him very much a Canadian intellectual. According to Arthur Kroker, the

Canadian mind may be one of the main sites in modern times for working-out the meaning of technological experience" and "a general fascination with the question of technology extends like a brilliant arc across the Canadian cultural imagination, from cinema and music to literature and philosophy. (Kroker 1984, 8)

These comments clearly are in harmony with Gould's thought. For Gould, technology serves as a gate to the North, to the realm of creative possibility that he thought he had already found.

Gould's conception of technology as a means of relocating music-making away from the public sphere and into the listener's privacy has gained new relevance with the emergence of the internet and interactive ways to listen to music enabled by technology. Gould, as early as the mid-1960's, talked about what he called the "kit-concept" of music: the idea that the re-creative listener, through his technological toolkit, would be able to edit, splice and combine different musics at will and thus create his own interpretation of music. Gould never saw his "toolkit" realized-nowadays any teenager can do these sorts of things (and much more) over the internet. As Timothy D. Taylor (2001, 138) has observed, "the computer and the retreat from the public seem to be resulting ... [in] new figurations of identity, as individuals who are separate from groups at the same time make affiliations with delocalized groups or 
causes." This is what Gould envisioned more than four decades ago. It took the "domestication" of the PC and the internet to realize his visions.

Gould also envisioned that technology would be there to make music and music-making anonymous. When recorded music becomes merely the raw material of a new listening experience, information pertaining to its original status (for instance, where it was composed) plays a less significant role in that new listening experience. This has actually taken place on the Web. Web sites abound where the user is able to access-for free or for a small fee-a sample bank of existing music, and a virtual sequencer with which he or she can create music and "publish" it and then leave it available for an unlimited number of other users. Gould wrote about this kind of technologically mediated "re-creative listening" more than 40 years ago-of course, in terms then available-and it is truly fascinating how many of his visions have become reality in our times. Technology, for Gould, provided access to the North-to solitude, private creative ecstacy and non-competition-and all this has become available to anyone with a curious mind and a computer. In this sense, we've all gone North.

\section{Conclusion}

In this essay, I have attempted a hermeneutic excursion into Glenn Gould's idea of North as expressed in his published statements. My argument consists of three basic points:

i. that Gould's idea of North is a broad aesthetic category which reflects itself on many levels in his thought;

ii. that this idea is important in Canadian cultural history, where there is such a thing as a "discursive formation of the North";

iii. that Gould's ideas also tie him to $19^{\text {th }}$-century discourses of absolute music and contemplative listening.

These ideas are by no means entirely new in the Gould literature. For instance, Kevin Bazzana, in his two wonderful books $(1997,2003)$, discusses Gould's ideas and musicianship critically, brilliantly and through a rich scholarly apparatus. What I have tried to emphasize, perhaps more than some scholars-Elizabeth Angilette (1992) being a good example-is a hermeneutic reading of Gould's ideas, a reading which tries to understand Gould in wider intellectual and cultural contexts. This hermeneutic reading, I believe, is not exhaustive. My purpose is not to reduce Gould's complex mind to the unfolding of a single idea. Neither have I tried to argue that this idea is somehow "caused" by Gould's living in Canada at a particular moment in the history of that country, in spite of the fact that many of his ideas are particularly "Canadian." What I have tried to do, instead, is to offer a reading of the central ideals of Gould's musical thought which relates them hermeneutically, not causally, to his own time and place, as well as the history of that time and place. 
As I see it, the Idea of North, in Gould's thought, works on four levels. First, on a personal level: Gould's own public image, the reception of his art, as well as his own personal fascination with the North. Second, on a musical level, Gould writes about music as an abstract, non-sensual, rational, and structural entity. He also emphasizes music's non-virtuosity, counterpoint, polyphony, which, in his thought, makes music a representation of "democratic" and "untotalitarian" qualities. Third, the North is reflected in what we could call the aesthetic level. Here Gould emphasizes the idea of "historical isolation," the potential of technology, contemplation and individual ecstasy as proper responses to music. And fourth, Gould, through his work and ideas, subscribes to a particularly Canadian "discursive formation of the North," as well as $19^{\text {th }}$-century ideas about listening to and interpreting music.

One of the most insightful writers on Gould, Edward Said (1991, 29), has argued that through the interplay of his recordings and written commentary Gould actually turned musical interpretation into a discursive space, in which there is no clear border between music and text. Gould, Said argues, extends his criticism from the written texts to music itself, and thus his musical interpretation functions as a sort of audible criticism of its object. In closing, I would like to propose an even more abstract idea: perhaps Gould's artistic voice should be listened to in the context of the Idea of North and the implication it has for aesthetic and ethic ideals, rather than in the $20^{\text {th }}-$ century pianistic tradition, in which he will always remain an eccentric, a figure who somehow does not fit. My essay is a modest hermeneutic attempt to do this. As Gould was a complex man, so were the intellectual and cultural frameworks in which his ideas find their true meaning.

\section{REFERENCE LIST}

Abbreviations (works listed in the bibliography under the name of their editor)

GGR = Glenn Gould Reader (Page 1990)

AGG = Art of Glenn Gould (Roberts 1999)

GGSL = Glenn Gould: Selected Letters (Roberts and Guertin 1992)

Angilette, Elizabeth. 1992. Philosopher at the Keyboard: Glenn Gould. Metuchen, NJ: Scarecrow Press.

Atwood, Margaret. 1993. "Survival." A Passion for Identity: An Introduction to Canadian Studies. Scarborough, Ontario: Nelson Canada, pp. 258-67. Bazzana, Kevin. 1997. The Performer in the Work. New York: Oxford University Press.

2003. Wondrous Strange: The Life and Art of Glenn Gould. Toronto: McClelland \& Stewart.

Cott, Jonathan. 1984. Conversations With Glenn Gould. Boston: Little, Brown \& Co.

Dahlhaus, Carl. 1989. Nineteenth-Century Music. California: University of California Press. 
1991. The Idea of Absolute Music. Chicago \& London: The University of Chicago Press.

Fink, Howard. 1997. "Glenn Gould's Idea of North." GlennGould Vol. 3/2, pp. 35-42.

Friedrich, Otto. 1990. Glenn Gould: A Life and Variations. New York: Vintage Books.

Foucault, Michel. 1997. The Archeology of Knowledge. London: Routledge. Frye, Northrop. 1971. The Bush Garden: Essays on the Canadian Imagination.

Toronto: Anansi.

1982. Divisions on a Ground. Toronto: House of Anansi Press Ltd. Gadamer, Hans-Georg. 1989. Truth and Method. London: Sheet \& Ward. Girard, François, and Don McKellar. 1993. Thirty-two Short Films about Glenn Gould. Dir. François Girard. Perf. Colm Feore. Prod. Niv Fichman. Rhombus Media

Goehr, Lydia. 1989. "Being True to the Work". Journal of Aesthetics and Art Criticism, 47: 55-67.

Gould, Glenn. 1963. Letter to Arthur Darack/The Cincinnati Enquirer. NLC (National Library of Canada) 21/24/21. (June 15, 1963; unpublished). . 1996. "Forgery and Imitation in the Creative Process." GlennGould 2/1, pp. 4-9. . 1998. "Glenn Gould on Recording." GlennGould vol. 4/1, pp. 3-4. 2001. "Glenn Gould: Concert Dropout." GlennGould vol. 7/2, pp. 46-60.

Gould, Glenn 2005 [1966]. Clip from a CBC television interview from 1966. URL: http://archives.cbc.ca/400d.asp?id=1-74-320-1686 (accessed 18 August 2005).

Grace, Sherrill E. 2002. Canada and the Idea of North. Canada: McGillQueen's University Press.

Guertin, Ghyslaine. 1988. "La technologie au service de l'extase dionysiaque." Glenn Gould, Pluriel Ghyslaine Guertin ed. Verdun, Québec: Louise Courteau, éditrice, pp. 233-46.

Hanslick, Eduard. 1986. On the Musically Beautiful. Geoffrey Payzant trans. Indianapolis: Hackett Publishing Co.

Harley, Maria Anna 1998. "Canadian Identity, Deep Ecology and R.Murray Schafer's 'The Princess of the Stars'." Northern Soundscapes, R. Murray Schafer Helmi Järviluoma eds. Tampere: Tampere University Press.

Hulan, Renée. 2002. Northern Experience and the Myths of Canadian Culture. Montreal \& Kingston: McGill's University Press.

Kivy, Peter. 1995. Authenticities. Ithaca, N.Y.: Cornell University Press.

Kroker, Arthur. 1984. Technology and the Canadian Mind. New York: St. Martin's Press.

Le Moyne, Jean. 1966. Convergences: Essays from Quebec. Toronto: Ryerson Press.

Leppert, Richard. 2002. Adorno's Essays on Music. California: University of California Press. 
McFarlane, Matthew. 2002. "Glenn Gould, Jean Le Moyne, and Pierre Teilhard de Chardin: Common Visionaries." GlennGould 2/2002, pp. 70-78. Mantere, Markus. 2002. "Kontrapunktissa maailman kanssa: eristäytymisen teema Glenn Gouldin musiikillisessa ajattelussa" [In Counterpoint with the World Outside: The Metaphor of Isolation in Glenn Gould's Musical Thought]. Etnomusikologian Vuosikirja 14, pp. 64-90.

McNeilly, Kevin. 1996. "Listening, Nordicity, Community: Glenn Gould's 'The Idea of North'." Essays on Canadian Writing, no59, Fall 1996, pp. 87-104.

Nattiez, Jean-Jacques. 1996. "The Language of Music in the Twenty-First Century: Gould as a Precursor of Postmodernism?" GlennGould 2/1996, pp. 28-35.

Nietzsche, Friedrich. 1967. The Case of Wagner. New York: Vintage. 2005. Beyond Good and Evil. Compiled from translations by Helen

Zimmern and Walter Kaufmann. http://www.geocities.com/ thenietzschechannel/bge.htm.

Page, Tim ed. 1990. The Glenn Gould Reader. New York: Vintage Books.

Payzant, Geoffrey. 1997. Glenn Gould: Music and Mind. Toronto: Key Porter Books Ltd.

Roberts, John P.L. ed. 1999. The Art of Glenn Gould. Toronto: Malcolm Lester Books.

Roberts, John P.L. and Ghyslaine Guertin. 1992. Glenn Gould: Selected Letters. Toronto: Oxford University Press.

Said, Edward. 1991. Musical Elaborations. New York: Columbia University Press.

2000. "Glenn Gould, the Virtuoso as Intellectual." Raritan XX:1, Summer, pp. 1-16.

Schafer, R. Murray. 1984. On Canadian Music. Bancroft, Ont.: Arcana. 1991. "Patria and the Theatre of Confluence." Descant 22/2 (Summer): 11-215.

Taylor, Timothy D. 2001. Strange Sounds: Music, Technology \& Culture. New York: Routledge.

Teachout, Terry. 2002. "Gouldism." Commentary. Dec.

Théberge, Paul. 1986. "Counterpoint: Glenn Gould and Marshall McLuhan." Canadian Journal of Political and Social Theory 10/1-2, pp. 109-27.

\section{ABSTRACT}

This article discusses the role played by the concept of "North" in Glenn Gould's musical thought. In Gould's writings and interviews, the meaning of the "North" is twofold:

(1) The concept refers to musical phenomena and qualities (counterpoint, non-virtuosity, sonic austerity) which were important for Gould's value judgments of music; (2) Gould used the concept as a metaphor, enabling him to bring together the ideas of isolation, the use of technology to creatively "opt-out," and the notion of non-competition into a coherent aesthetic and 
ethical perspective. Through a study of Gould's written documents, the concept of "North" will be examined to establish a hermeneutic framework within which to better appreciate and evaluate Gould's musicianship.

\section{RÉSUMÉ}

Cet article examine le rôle joué par le concept de "Nord " dans la pensée musicale de Glenn Gould. Dans les écrits et entretiens de Gould, la signification du « Nord " est double :

(1) Le concept renvoie au phénomène musical et aux qualités (contrepoint, non virtuosité, austérité acoustique) qui étaient importantes pour Gould dans ses jugements de valeur sur la musique; (2) Gould utilise le concept comme métaphore, lui permettant de réunir les idées d'isolement, d'utilisation de la technologie afin de "s'évader " créativement et celle de non-compétitivité au sein d'une esthétique cohérente et d'une perspective éthique. À travers l'étude d'écrits de Gould, le concept du " Nord » sera étudié afin d'établir un cadre herméneutique permettant de mieux apprécier et juger du sens musical de Gould. 